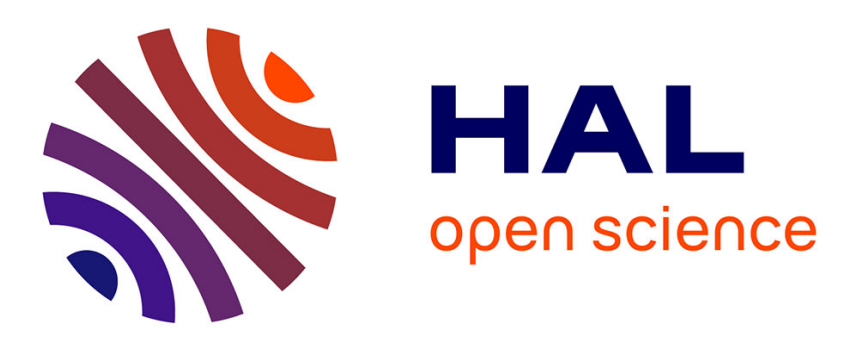

\title{
XAFS Study of Structural Evolution During Calcination of Two Zinc-Chromium Based Lamellar Double Hydroxides
}

\author{
A. Ennaqadi, M. Khaldi, A. de Roy, Claude Forano, J. Besse
}

\section{- To cite this version:}

A. Ennaqadi, M. Khaldi, A. de Roy, Claude Forano, J. Besse. XAFS Study of Structural Evolution During Calcination of Two Zinc-Chromium Based Lamellar Double Hydroxides. Journal de Physique IV Proceedings, 1997, 7 (C2), pp.C2-1231-C2-1232. 10.1051/jp4:19972208 . jpa-00255280

\author{
HAL Id: jpa-00255280 \\ https://hal.science/jpa-00255280
}

Submitted on 1 Jan 1997

HAL is a multi-disciplinary open access archive for the deposit and dissemination of scientific research documents, whether they are published or not. The documents may come from teaching and research institutions in France or abroad, or from public or private research centers.
L'archive ouverte pluridisciplinaire HAL, est destinée au dépôt et à la diffusion de documents scientifiques de niveau recherche, publiés ou non, émanant des établissements d'enseignement et de recherche français ou étrangers, des laboratoires publics ou privés. 


\title{
XAFS Study of Structural Evolution During Calcination of Two Zinc-Chromium Based Lamellar Double Hydroxides
}

\author{
A. Ennaqadi, M. Khaldi, A. de Roy, C. Forano and J.P. Besse \\ Laboratoire de Physico-Chimie des Matériaux, URA 444 du CNRS, 63177 Aubière Cx, France
}

\begin{abstract}
Two [Zn-CrШ] Lamellar Double Hydroxides respectively intercalated by chloride and sulphate anions were prepared and two series of samples were obtained by heating these two compounds at increasing temperatures. At temperatures higher than $200^{\circ} \mathrm{C}$ these compounds become ill-organized materials. The lamellar structure collapses at about $300^{\circ} \mathrm{C}$ leading to highly divided amorphous oxides. A spinel-like phase and zinc oxide crystallise at high temperatures. The EXAFS study at $\mathrm{Zn}$ and $\mathrm{Cr} \mathrm{K}$-edges shows clearly the presence of a pre-spinel organisation in the ill-organized samples at intermediate temperature range. The XANES spectra at $\mathrm{Cr} \mathrm{K}$-edge evidence the formation of small amounts of $\mathrm{Cr} V$ which disappears at higher temperatures. These behaviours are observed at slightly different temperatures for both sulphate and chloride intercalated precursors.
\end{abstract}

\section{INTRODUCTION}

Lamellar Double Hydroxides (LDHs) are based on brucite-like $\mathrm{M}(\mathrm{OH})_{2}$ layers containing mixed MII, MII metallic cations.

The general formula:

$$
\left[\mathbf{M}_{(1-\mathbf{x})}^{\mathrm{II}} \mathbf{M}_{\mathbf{x}}^{\mathrm{II}}(\mathrm{OH})_{2}\right]^{\mathrm{x+}}\left[\mathbf{X}_{\mathrm{x} / \mathrm{p}}^{\mathrm{p}-\mathrm{w}} \cdot \mathbf{n H}_{2} \mathrm{O}\right]^{\mathrm{x}-}
$$

gives prominence to the positively charged main layers separated by charge balancing interlamellar domains of solvated $\mathrm{X}$ anionic species; we shall use the short notation [Mח-Mm-X]. These materials display a broad spectrum of potential applications and one of the main fields of research is their use as catalysts and precursors of catalysts $[1,2]$. By controlled calcination, they lead to highly divided amorphous oxides. It is therefore necessary to characterise accurately their thermal evolution.

In previous works [3-4] we studied, the $[\mathrm{Zn}-\mathrm{Cr}-\mathrm{Cl}]$ and $\left[\mathrm{Zn}-\mathrm{Cr}-\mathrm{SO}_{4}\right] \mathrm{LDHs}$. These compound were prepared by the coprecipitation methods [5] with a $x=1 / 3$ trivalent metal ratio. Crystal structures were studied by the Rietveld method on PXRD data. The thermal evolution of these precursors was also followed by Thermo-Gravimetric, Differential Thermal Analysis, Infra-Red spectroscopy and Powder X-Ray Diffraction (PXRD) measurements. At low temperatures $\left(20-300^{\circ} \mathrm{C}\right)$, the LDH structure evolves with changes in the basal spacing and stacking sequence of the layers. At high temperatures (more than $800^{\circ} \mathrm{C}$ ) well crystallised $\mathrm{ZnO}$ and $\mathrm{anCr} \mathrm{Zn}_{4}$ spinel-like phase are obtained. The intermediary temperature domain from $300^{\circ} \mathrm{C}$ to $450^{\circ} \mathrm{C}$ displays very illorganised materials.

In this paper we give some XAFS results on the temperature related structural evolution of these compounds. Samples were heated overnight in air at thirteen different temperatures up to $1030^{\circ} \mathrm{C}$ and characterised at room-temperature. XAFS transmission mode measurements at $\mathrm{Zn}$ and $\mathrm{Cr} \mathrm{K}$-edges, were performed the LURE, EXAFS IV station on DCI ring. Absorption data was processed with the software written by A. Michalowicz. [6-8] In this short report, experimental data is only given for some selected calcination temperatures of the $\left[\mathrm{Zn}-\mathrm{Cr}-\mathrm{SO}_{4}\right]$ precursor.

\section{EXAFS CHARACTERISATION}

\subsection{Zn K-edge}

The absorption was measured in the $9600-10600 \mathrm{eV}$ range with a 2 $\mathrm{eV}$ step. The $\mathrm{k} 3 \chi(\mathrm{k})$ radial distributions of selected samples at zinc $\mathrm{K}$-edge are reported in Figure 1 . The $\left[\mathrm{Zn}-\mathrm{Cr}-\mathrm{SO}_{4}\right]$ precursor 0.0 displays two main peaks; the first one corresponds to the six oxygen atoms of hydroxyl groups octahedrally surrounding the zinc

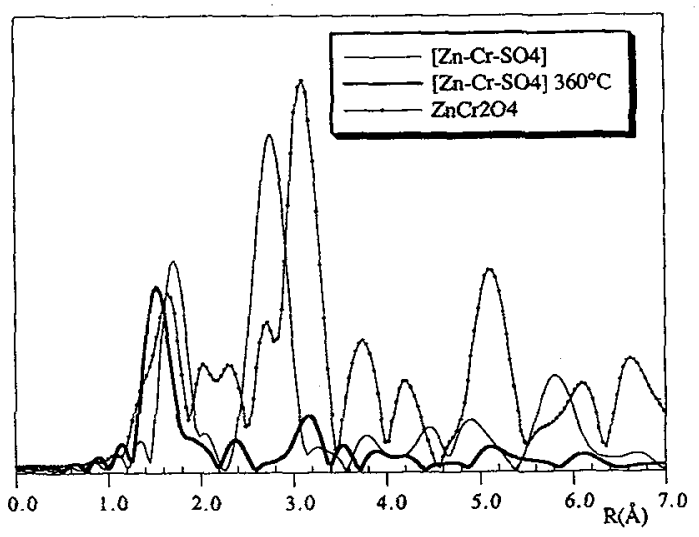

Figure 1; $\mathrm{k}^{3} \chi(\mathrm{k})$ Radial distribution at zinc K-edge 
atoms and the second one to the six nearest metallic cations in the $\mathrm{LDH}$ main layer. By heating at $360^{\circ} \mathrm{C}$ a quasi amorphous oxysulphate is obtained; as the LDH structure collapse, the second peak disappears and the first peak shifts to a lower distance, very close to the one observed in zinc oxide and shorter than in the $\mathrm{ZnCr}_{2} \mathrm{O}_{4}$ spinel-like phase obtained at $1100^{\circ} \mathrm{C}$ from $\mathrm{ZnO}$ and $\mathrm{Cr}_{2} \mathrm{O}_{3}$. However the global shape of radial distribution is similar to $\mathrm{ZnCr}_{2} \mathrm{O}_{4}$.

\subsection{Cr K-edge}

The absorption was measured in the $5930-6930 \mathrm{eV}$ range with a 2 eV step. The $\mathrm{k}^{3} \chi(\mathrm{k})$ radial distributions at chromium $\mathrm{K}$-edge are reported in Figure 2. For the [ $\left.\mathrm{Zn}-\mathrm{Cr}-\mathrm{SO}_{4}\right]$ precursor, the two main peaks correspond respectively to the same neighbouring atoms as at $\mathrm{Zn} \mathrm{K}$-edge. The $360^{\circ} \mathrm{C}$ heated sample radial distribution looks very 0.0 close to the one of the $\mathrm{ZnCr}_{2} \mathrm{O}_{4}$ phase. On the opposite to the behaviour observed at $\mathrm{Zn} \mathrm{K}$-edge, the position of the first peak corresponding to $\mathrm{Cr}-\mathrm{O}$ distances remains constant.

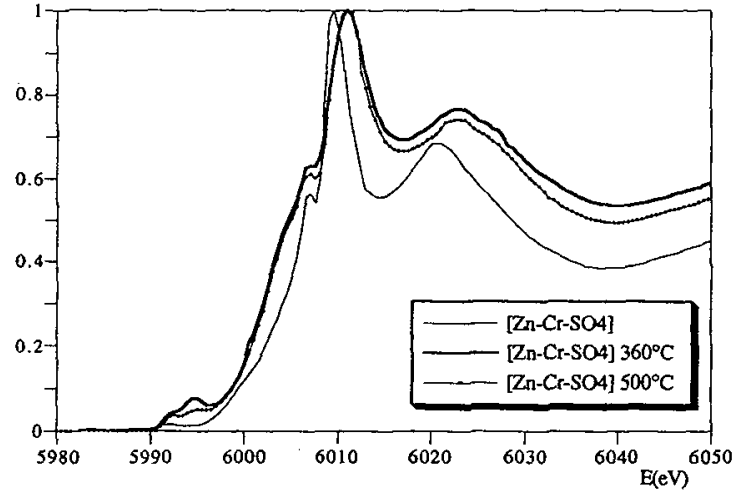

Figure 3: XANES spectra at chromium K-edge

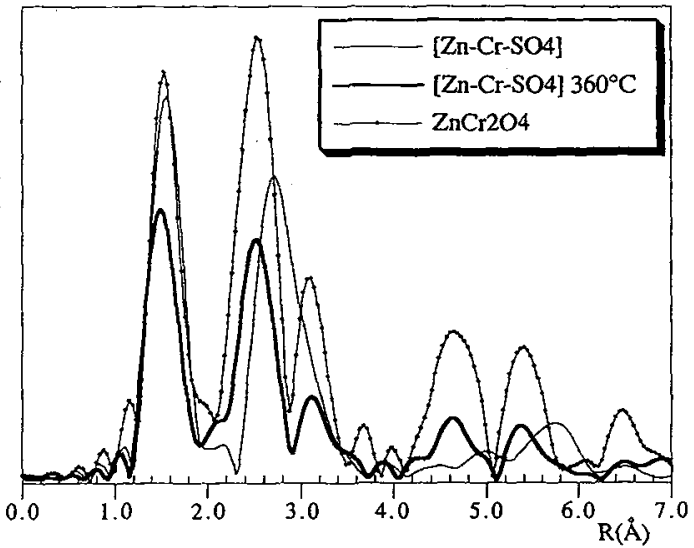

Figure 2: $\mathbf{k}^{3} \chi(\mathrm{k})$ Radial distribution at chromium $\mathrm{K}$-edge

\section{XANES CHARACTERISATION}

The measurements were performed at the Cr K-edge (5980-6020 eV with a $0.5 \mathrm{eV}$ step). For all of the samples, the K-edge displays the same global shape consistent with octahedrally surrounded CrII moieties. Compared with the calcined samples, the white band of the $\mathrm{LDH}$ precursor $(6009.5 \mathrm{eV})$ is observed at a lower energy $(\approx 2$ $\mathrm{eV}$ ). A remarkable feature is the presence of a small pre-peak at $5994.2 \mathrm{eV}$ for all samples since dehydroxylation of LDH layers $\left(200^{\circ} \mathrm{C}\right)$ which disappears at higher temperatures $\left(500^{\circ} \mathrm{C}\right)$. This prepeak is obviously related to the presence of small amounts of $\mathrm{Cr}$ VI in this temperature range.

The EXAFS study of the [ $\mathrm{Zn}-\mathrm{Cr}-\mathrm{SO}_{4}$ ] Lamellar Double Hydroxides is consistent with the early formation of a pre-spinel shortrange organisation in the ill-organised materials obtained at $300-450^{\circ} \mathrm{C}$. Such structural relationship between lamellar atacamite and spinel-like structure was reported elsewhere [9]. Mainly in the same temperature range, the formation of small amounts of $\mathrm{CrVI}$ is evidenced by the XANES study; at higher temperatures only $\mathrm{Cr} m$ remains. The $[\mathrm{Zn}-\mathrm{Cr}-\mathrm{Cl}]$ phase displays a similar behaviour under thermal treatment but the sulphate intercalated material displays a higher thermal stability.

Acknowledgements: We are grateful to the staff of LURE (Orsay) for their assistance in facilitating our experiments.

\section{References}

[1] Cavani F., Trifiro F., Vaccari A., Catal. Today 11 (1991) 173-291.

[2] de Roy A., Forano C., El Malki K., Besse J.P., Synthesis of Microporous Materials vol. II - Expanded Clays and other Microporous Solids (Occelli M.L., Robson H.E. editors, Van Nostrand Reinbold, New York, 1992) pp. 108-169.

[3] Ennadi A., Khaldi M., de Roy A., Besse J.P., Mol. Cryst. Liq. Cryst. 244 (1994) 373-378.

[4] Khaldi M., Synthèse de Diverses Variétés d'Hydroxydes Doubles Lamellaires Intercalés par des Anions Sulfate et séléniate: Caractérisation Structurale et Electrique, Ph.D. Thesis, Universite Blaise Pascal, Clermont-Ferrand France (1995).

[5] Miyata S., Clays and Clay Minerals 23 (1975) 369-375.

[6] Michalowicz A., Logiciels pour la Chimie (Société Française de Chimie, Paris, 1991) pp. 102-103.

[7] Noinville V, Michalowicz A., Logíciels pour la Chimie (Société Française de Chimie, Paris, 1991) pp. $116-117$.

[8] Michalowicz A., André D., Logiciels pour la Chimie (Société Française de Chimie, Paris, 1991) pp. 148-149.

[9] Parise J.B., Hyde B.G., Acta Cryst. C42 (1986) 1277-1280. 